\title{
Living with or Eradicating Poisonous Snakes in Densely Populated Caribbean Islands-A Socio-Ecological Challenge for the French West Indies
}

\author{
Jean-Raphaël Gros-Désormeaux ${ }^{1}{ }^{*}$, Erwann Lagabrielle ${ }^{2}$, Thierry Lesales ${ }^{3}$, Isabelle Exilie ${ }^{4}$, \\ Lise Tupiassu $^{5}$, Dimitri Béchacq ${ }^{1}$ \\ ${ }^{1}$ UMR 8053 LC2S, Centre National de la Recherche Scientifique, Campus de Schoelcher, Cedex, France \\ ${ }^{2}$ UMR 228 ESPACE-DEV, Universite de La Reunion, Institut de Recherche pour le Developpement, Sainte-Clotilde, France \\ ${ }^{3}$ Research center EA 929 AIHP-GEODE Caraïbe, Université des Antilles, Campus de Schoelcher, Cedex, France \\ ${ }^{4}$ UFR Mixte de Médecine et de Pharmacie, Université de Rouen, Haute Normandie, Cedex, France \\ ${ }^{5}$ Universidade Federal do Pará, Instituto de Ciênciasjurídicas, Cidade Universitária Prof. José da Silveira Netto, Belém, Brésil \\ Email: `jrmgrosdesormeaux@yahoo.fr, erwann.lagabrielle@gmail.com, thierry.lesales@gmail.com, 1tupiassu@gmail.com, \\ isabelle.exilie@wanadoo.fr, d.bechacq@free.fr
}

How to cite this paper: Gros-Désormeaux, J.-R., Lagabrielle, E., Lesales, T., Exilie, I., Tupiassu, L. and Béchacq, D. (2017) Living with or Eradicating Poisonous Snakes in Densely Populated Caribbean Islands-A Socio-Ecological Challenge for the French West Indies. Open Journal of Animal Sciences, 7, 405-413. https://doi.org/10.4236/ojas.2017.74031

Received: July 5, 2017

Accepted: September 19, 2017

Published: September 22, 2017

Copyright $\odot 2017$ by authors and Scientific Research Publishing Inc. This work is licensed under the Creative Commons Attribution International License (CC BY 4.0).

http://creativecommons.org/licenses/by/4.0/ (c) (i) Open Access

\begin{abstract}
The lancehead (Bothrops lanceolatus) is a poisonous snake endemic to Martinique, an island in the Lesser Antilles arc. Today, this snake is on the verge of extinction. The recorded number of snakes killed yearly between 1970 and 2002 decreased by $97 \%$. Despite the production of an antivenom in 1993, the local authorities set up a financial reward to encourage the eradication of lancehead snakes. Today the local population still perceives the snake as a threat, due to its fatal venom and its fierce behaviour. The case study of the lancehead in Martinique highlights the need to develop integrated strategies to conserve species of poisonous snakes on densely populated islands. This requires innovative, cross-sectoral strategies that involve decision-makers working along with multi-disciplinary scientists. Approaching the complexity of ecosystems through the socio-ecological prism implies, conversely, linking up the domains of science and technology, life and environmental sciences, and human and social sciences, through interactions based on sharing common assumptions.
\end{abstract}

\section{Keywords}

Caribbean Islands, Conservation, Endemic Species, Nature-Society, Snake 


\section{Introduction}

In 2011, the IUCN Red List estimated that 627 snake species are threatened all around the world. A recent study by Reading [1] explains and illustrates that snake species populations are declining around the globe. Additionally, the challenges and the opportunities for biodiversity conservation are represented in particular by 120 snake species representing six families of which 115 are endemic to the Caribbean islands hotspot [2]. Whereas the species richness in the Lesser Antilles is only 25 snakes, the number of extirpations and extinctions is between six and 11 species [3]. The main cause of biodiversity loss is the habitat loss associated with the growth of human population size and density; populations of island snakes are isolated and they frequently have small areas of occupancy [4].

This study focuses on the lancehead Bothrops lanceolatus. This snake is the only poisonous snake endemic to Martinique, a French island of $1100 \mathrm{~km}^{2}$ totaling 403,000 inhabitants. Martinique is part of the archipelago of the Lesser Antilles in the Caribbean Sea. Lancehead bites can result in partial paralysis and death [5]. Approximately 20 - 30 people are bitten annually in Martinique [6]. Consequently, this snake is routinely killed when encountered by humans [7].

The aim of this study is to present the socio-ecological context for the lancehead Bothrops lanceolatus conservation. Without questioning the equal consideration for animals developed by Singer [8], environmental regulation cannot lose sight of the interest of conserving a species, even if its presence poses health risks. Analysed from the socio-ecological system perspective, thought needs to be given to the framework for balancing conflicting interests. The study of the complex interactive processes between social systems and ecological systems calls for a better understanding of the impact of disturbances on the resilience of ecosystems and the maintenance of ecosystem services. The concept of a socio-ecological system was therefore proposed to analyse the interactions between a society and an ecosystem, in order to promote their joint management [9]. This school of thought, built up around ecology experts and environmental economists, disseminates a number of its works through its journal Ecology and Society, with the aim of improving the "sustainable development" of socio-ecological systems.

\section{The Martinique Lancehead Ecological Issue}

The size of the Martinique lancehead varies between 10 to $300 \mathrm{~cm}$, with a diameter reaching up to $7 \mathrm{~cm} \mathrm{[10]} \mathrm{[11].} \mathrm{Compared} \mathrm{to} \mathrm{the} \mathrm{males,} \mathrm{the} \mathrm{females} \mathrm{have} \mathrm{a}$ longer and bigger body, a stronger and more triangular head, a thinner and shorter tail [10]. The Martinique lancehead gives birth to more than 60 snakes [12] [13].

The spatial distribution of the Martinique lancehead has been characterized from observations, registered bites and captures. Based on the accounts by the first chroniclers, the Martinique lancehead used to be found widely on the entire 
island [12] [13] [14] [15] [16]. However, in 1964, Lazell thought that Bothrops lanceolatus was mainly found inland [10]. Until the end of the 1970s, the populations of Bothrops lanceolatus still occupied a wide part of Martinique.

The Martinique Lancehead habitat is primarily located in bioclimatic zones ranging from humid to dry [11]. The snake haunts the vicinity of streams and other areas with low anthropic activity. Bothrops lanceolatus generally hides in the woods, in other animals' burrows, under rocks, in hollow trees, under windthrows, in thickets and bushes, in neglected sugar-cane fields, or other crops such as bananas and pineapples; in some areas, more rarely, the snake can also be found in gardens [12] [13] [15] [16] [17] [18] [19]. Agricultural crops that are poorly maintained and infested by black rats Rattus rattus are also habitats for Bothrops. It can very accidentally be found in urbanized areas. This snake feeds on birds, eggs, small reptiles, insects, amphibians, and other species of ophidians. Although it apparently has terrestrial habits, it is important to note that this snake can occasionally be observed on tree branches.

The lancehead Bothrops lanceolatus, which belongs to the order of Squamata, Viperidae family, originated from South America. The results of a mitochondrial sequence of its DNA [20] [21] [22] reaffirmed a slight genetic variation between the West-Indian species and the Bothrops asper-atrox of South America. The genetic gap between the insular species and its continental phylogenetic kin is thought to be located between the end of the Miocene period and the beginning of the Pliocene. Therefore, Bothrops lanceolatus is not a recent secondary taxonomic evolution of the widely spread South American kind; the Martinique lancehead rather belongs to an independent and relatively old speciation. The analysis of morphological data reveals that the insular colonization by the Bothrops genus happened in two phases: first, a migration from the South American continent towards St. Lucia; second, a migration from St. Lucia towards Martinique. An analysis of the genetic distance between $B$ caribbaeus and $B$ lanceolatus shows that the genetic flow to Martinique was not continuous through time.

\section{The Island People's Perception of the Snake}

The collection of testimonies compiled by du Tertre [15] and Coadou [23] presents Bothrops lanceolatus as being a mythical animal at once feared, hunted, and respected. Many inhabitants of Martinique perceive it as a symbol of everything that has negative connotations. In many West Indian proverbs, it is related to treachery, wickedness, or misfortune. It is used in the practice of the local black magic, or "Kimbois": its head is thought to be useful for making bewitching potions, its fangs serve to poison crops. In many stories, the snake is presented as a supernatural being. We note the incredible story told by du Tertre [15] on a snake "sucking" the breasts of a West Indian woman. We recall the tale of the snake coiling itself around a vehicle. The most evocative image is that of a twin relationship between a child and a snake. 
Any snake seen near a house or any other place frequented by man, is generally tracked down until it is killed. The association between its deadly venom and its great discretion makes it an enemy dreaded by the island's populations. The first chroniclers reported many deaths from snakebites. The victims most frequently mentioned were the farmers engaged in sugar cane cutting in the plantations of that time. Nowadays, the fields are regularly burned before the cutting and are, therefore, no longer the preferred biotope of the lancehead Bothrops lanceolatus. However, the main victims remained agricultural workers until the end of the 20th century [24]. Finally, as a symbolic representation of cunning, dignity, and victory, it is drawn in a defensive position on the four quarters of Martinique's maritime flag.

The snake therefore occupies a mythical place in Martinique's tradition. As a symbol of evil and power, it seems to permeate the imagination of indigenous peoples. It is present in stories that are told from generation to generation. Being the personification of evil in the minds of natives of Martinique, it was and still is regularly tracked down.

\section{The Historical Framework to Eradicate the Snake}

The number of snakes killed yearly in Martinique has been recorded from 1970 to 2002. This data was recorded within the framework of an eradication programme initiated in 1970: the local authorities offered a 20 US dollars' reward for any lancehead killed. Over this period, the number of killed snakes dropped by $97 \%$ : from 12,000 snakes killed in 1970 down to 386 in 2002 [25]. Since 2002, the population trend was undetermined. During this period, the hunting effort also dropped. Snake hunters interviewed said they tracked the snake less frequently, due to the lack of the resource and to the end of the 20 US\$ reward offered by authorities [26]. The number of viper hunters, whose average age is 60 , is also dropping significantly.

Nevertheless, the decreasing number of killed lanceheads is only partially explained by a fall in the hunting effort. The drop in lancehead sightings and a decrease in the number of bites is strong evidence that the snake is disappearing in Martinique [25].

The local population and authorities still perceive and cope with the snake as a fatal threat, not as a conservation stake. Although an antivenom was produced in 1993 [24] and completely removed the mortality risk for the human population, the reward program for killed lanceheads was only stopped in 2002 .

Other threats to the lancehead snake include: habitat modification due to development and habitat modification to sustain the human population. The ecological niche of Bothrops lanceolatus represents less than $50 \%$ of the total area of Martinique island [27]. Habitat fragmentation could have consequences on population size and may induce loss of genetic variation due to inbreeding [28] [29]. Daltry [30] cites those factors as the major threats for the critically endangered Antiguan racer Alsophis antiguae. 


\section{How to Develop a Social Promotion of the Snake's Conservation?}

The foregoing eradication strategy, and the lack of a conservation programme to protect endemic lancehead populations in Martinique, do not comply with the world convention on biological diversity signed by France. The extinction of the Martinique lancehead is not an acceptable solution. The risks associated with this poisonous snake need to be managed. The disappearance of viper hunting and the possible proliferation of the poisonous snake could represent a risk for inhabitants. However, the conservation of the snake could be turned into an opportunity for developing socio-economic activities. For instance, the venom of close species, such as Bothrops atrox, contains rare chemical elements with haemostatic properties, used for the treatment of haemorrhages and epilepsy [31]. The venom of Martinique lancehead could also contain similar elements.

Indeed, once inoculated, the venom is rapidly absorbed and then widely diffused via the whole vascular system. This first aspect reveals its molecular transport abilities. Secondly, it has a crototoxin-like toxin which blocks neuromuscular transmissions via a specific receptor. This suggests the existence of a natural physiological feedback and makes it possible to envisage its use. From a strictly haematological point of view, snake venom produces convulxin, a powerful platelet activator. But it also contains a specific inhibitor of human thrombin. In the cascade reaction of blood coagulation, thrombin leads to the formation of the fibrin network, which is the main component of the blood clot. An antithrombotic application of venom proteins therefore seems possible. Knowledge of the venom has revealed a biofeedback, in this case a negative feedback loop controlling the procoagulant action of activated blood platelets. These observations undeniably open up perspectives for the understanding and perhaps the programmed regulation of physiological processes involved in blood coagulation. Some venom proteins can be used in the improvement of therapeutic agents for thrombopathias and/or cardiovascular and cerebrovascular accidents. Cardiovascular diseases are the first causes of death in developed countries and much more so under our latitudes. Such a therapeutic resource, therefore, cannot be neglected. In this respect, venom peptides are used in heart surgery to make the blood more fluid in very heavy operations during which particularly dreaded clots may form. "Tirofiban" is already being used in hospitals to prevent early myocardial infarction in some patients.

Furthermore, the Pasteur institute is studying the possibility of developing, after the purification of peptides, an active principle capable of dissolving very quickly the clots involved in cerebrovascular accidents caused by the obstruction of a blood vessel by a blood clot. In this enumeration of the venom's potentialities, a pharmacist would not forgive the omission of the therapeutic use, well established in homeopathy, of Lachesis mutus, a major medication for menopause. Indeed, whereas the Hormone Replacement Therapy (HRT) for menopause delays the programmed time of ovarian pause, the homeopathic replica improves 
the climacteric symptoms (hot flashes, night sweats, irritability, depression, general weariness, volubility). Here as well, venom offers an alternative to women who, either for ideological reasons, or for medicinal or strictly medical reasons, cannot use the menopause hormone therapy. It should be noted that rare chemical elements with haemostatic properties present in the venom of Bothrops atrox which is found in Guyana, are already being used by simple purification in the laboratory for preventive and curative treatments of most haemorrhages and in the reduction of epilepsy [31].

In view of the real pharmaceutical potential that snake venom offers, it is therefore necessary to reconcile conservation, development and risk management toward the integrated conservation of lancehead Bothrops lanceolatus in Martinique. Overall, the conservation of the snake will require innovative, cross-sectoral strategies involving public decision-makers and multi-disciplinary scientists.

\section{Conclusions}

Finally, living with poisonous snakes on densely populated islands should involve an innovative conservation project that includes developing and enforcing protective national and international legislation for endemic species and their habitats; increasing public awareness about the regional importance and benefits of the poisonous snake; monitoring the size, status, and demography of the population; implementing a research project to survey the spatial distribution; building local capacity in conservation and valorisation techniques through training and provision of essential equipment.

People must see beyond anthropocentrism in order to guarantee a harmonious living of all animals on earth [32]. The socialisation of nature suggested by this approach to humans' relationships with their environment refers to analogism, as defined by Descola [33]. The concept of the socio-ecological system and its process of regional analysis [34] [35] recalls here the need to include social and political compartments in the knowledge of ecosystems, their interactions, and their functions [36]. On this point, the compartmentalisation of scientific domains tends to produce a splintered approach in the analysis of changes that have occurred since the beginning of the Anthropocene Era, namely since the great scientific and industrial revolutions of the $18^{\text {th }}$ century. In fact, in spite of notable conceptual advances, such as Ludwig Von Bertalanffy's general system theory in 1968, the scientific domains conform to cognitive and normative matrices influenced by reductionism. Approaching the complexity of ecosystems through the socio-ecological prism implies, conversely, linking up the domains of science and technology, life and environmental sciences, and human and social sciences, through interactions based on sharing common assumptions [37]. Recent thinking on this issue has therefore led to focusing on the institutions' capacity for maintaining territories in a stable state and creating opportunities for change to reach another stable state [34] [38]. 


\section{Acknowledgements}

This work benefited from the support of "Investissements d'Avenir" of the French National Agency for Research (CEBA, ref. ANR-10-LABX-25-01). We are grateful to the French West Indies University (Université des Antilles) and the Martinique Regional Nature Park for their administrative support. We also would like to thank Maurice Burac and Michel Tanasi for their professional and technical management, and D. Laurent Thomas, D. Daniel Vigée, D. Bernard Bucher, and D. Janine Kétterlé for their help. Finally, we do not forget Philippe Cléry, who assisted with fieldwork, Gloria Lesales, and Atenao who helped to improve this article.

\section{References}

[1] Reading, C.J., Luiselli, L.M., Akani, G.C., Bonnet X., Amori, G., Ballouard, J.M., Filippi, E., Naulleau, G., Pearson, D. and Rugiero, L. (2010) Are Snake Populations in Widespread Decline? Biology Letters, 6, 777-780.

https://doi.org/10.1098/rsbl.2010.0373

[2] Tolson, P.J. and Henderson, R.W. (2006) An Overview of Snake Conservation in the West Indies. Applied Herpetology, 3, 345-356. https://doi.org/10.1163/157075406778905054

[3] Henderson, R.W. (2004) Lesser Antillean Snake Faunas: Distribution, Ecology, and Conservation Concerns. Oryx, 38, 311-320. https://doi.org/10.1017/S0030605304000559

[4] Martins, M. and Nilson, G. (2008) Snakes on Islands: Ecology, Evolution and Conservation. South American Journal of Herpetology, 3, 122-122. http://www.bioone.org/doi/abs/10.2994/1808-9798(2008)3\%5B122:SOIEEA\%5D2.0. $\mathrm{CO} \% 3 \mathrm{~B} 2$

[5] Thomas, L., Tyburn, B., Ketterle, J., Biao, T., Mehdaoui, H., Moravie, V., Rouvel, C., Plumelle, Y., Bucher, B., Canonge, D., Marie-Nelly, C.A. and Lang, J. (1998) Prognostic Significance of Clinical Grading of Patients Envenomed by Bothrops lanceolatus in Martinique. Transactions of the Royal Society of Tropical Medicine and Hygiene, 92, 542-545. https://doi.org/10.1016/S0035-9203(98)90907-5

[6] Resiere, D., Mégarbane, B., Valentino, R., Mehdaoui, H. and Thomas, L. (2010) Bothrops lanceolatus Bites: Guidelines for Severity Assessment and Emergent Management. Toxins, 2, 163-173. https://doi.org/10.3390/toxins2010163

[7] Powell, R. and Henderson, R.W. (2005) Conservation Status of Lesser Antillean reptiles. Iguana, 12, 62-77.

https://www.researchgate.net/profile/Robert_Henderson6/publication/264838520 Conservation_Status_of_Lesser_Antillean_Reptiles/links/540ee70e0cf2f2b29a3c3f28.pdf

[8] Singer, P. (1986) Animal Liberation: A Personal View. Between the Species, 2, 148-154.

http://digitalcommons.calpoly.edu/cgi/viewcontent.cgi?article=1603\&context=bts

[9] Berkes, F. and Folke, C. (1998) Linking Social and Ecological Systems: Management Practices and Social Mechanisms for Building Resilience. Cambridge University Press, Cambridge, UK.

[10] Lazell, J.D. (1964) The Lesser Antillean Representative of Bothrops and Constrictor. Bulletin of the Museum of Comparative Zoology, 132, 245-273. 
http://biostor.org/reference/778

[11] Carrasco, P.A., Mattoni, C.I., Leynaud, G.C. and Scrocchi, G.J. (2012) Morphology, Phylogeny and Taxonomy of South American Bothropoid Pitvipers (Serpentes, Viperidae). Zoologica Scripta, 41, 109-124. http://www.cnah.org/pdf/88323.pdf

[12] Rufz, E. (1859) Enquête sur le Serpent de la Martinique. Germer Baillière, Paris.

[13] De Lalung, H. (1934) Le Serpent de la Martinique. Laboratoires Corbière, Paris.

[14] Bouton, J. (1640) Relation de l'establissement des Français depuis l'an 1635 en Isle de la Martinique, l'une des Antilles de l'Amérique. Editions Cramoisy, Paris. http://gallica.bnf.fr/ark:/12148/bpt6k111221c/f1.image.r=.langEN

[15] Du Tertre, J.B. (1671) Histoire générale des Antilles habitées par les françois. Editions CEP, Fort-de-France. http://gallica.bnf.fr/ark:/12148/bpt6k114022z

[16] Labat, J.B. (1722) Nouveau voyage aux isles d'Amérique. Editions Des Horizons, Fort-de-France. http://gallica.bnf.fr/ark:/12148/bpt6k5545370j.r

[17] Moreau de Jonnes, A. (1816) Monographie du Trigonocéphale des Antilles ou grande vipère fer-de-lance de la Martinique. Editions Migneret, Paris.

http://www.manioc.org/gsdl/collect/patrimon/archives/NAN13003.dir/NAN13003. pdf

[18] Cornillac, J.J. (1892) La faune des halliers, des savanes et des forêts: Le bothrops lancéolé. Les Colonies, Fort-de-France.

[19] Bassières, E. (1916) La lutte contre le serpent. Journal officiel, Fort-de-France.

[20] Salomão, M.G., Wüster, W., Thorpe, R.S. and BBBSP (1999) MtDNA Evolution in Neotropical Pitvipers of the Genus Bothrops (Squamata: Serpentes: Viperidae). [Article title in English.] Kaupia, 8, 127-134.

http://pages.bangor.ac.uk/ bss024/pdfs/2002/Wuster\%20Biol\%20Viper\%20Chapter \%202002.pdf

[21] Wüster, W., Salomão, M.G., Duckett, G.J., Thorpe, R.S. and BBBSP (1999) Mitochondrial DNA Evolution of the Bothrops atrox Species Complex (Squamata: Serpentes: Viperidae). [Article title in English.] Kaupia, 8, 135-144. http://pages.bangor.ac.uk/ bss024/pdfs/1999/Wuster\%20Kaup\%201999.pdf

[22] Wüster, W., Thorpe, R.S., Salomão, M.G., Thomas, L., Puorto, G., Theakston, R.D.G. and Warrell, D.A. (2002) Origin and Phylogenetic Position of the Lesser Antillean Species of Bothrops (Serpentes: Viperidae): Biogeographical and Medical Implications. Bulletin of the Natural History Museum London (Zoology), 68, 101-106. https://doi.org/10.1017/S0968047002000110

[23] Coadou, M. (2000) Serpent, manicou et... dorlis. Bestiaire symbolique martiniquais. Ibis rouge, Petit-Bourg.

[24] Thomas, L., Tyburn, B., Bucher, B., Pecout, F., Ketterle, J., Rieux, D., Smadja, D., Garnier, D. and Plumelle, Y. (1995) Prevention of Thromboses in Human Patients with Bothrops lanceolatus Envenoming in Martinique: Failure of Anticoagulants and Efficacy of a Monospecific Antivenom. The American Journal of Tropical Medicine and Hygiene, 52, 419-426.

http://www.ajtmh.org/content/52/5/419.full.pdf

[25] Gros-Désormeaux, J.R. and Burac, M. (2002) Biogéographie insulaire, zoogéographie des populations de Bothrops dans les écosystemes tropicaux de la Martinique et de Sainte-Lucie. Unpublished Report for Université des Antilles et de la Guyane Schoelcher.

[26] Gros-Désormeaux, J.R. (2004) La traque aux Trigonocéphales (Bothrops lanceolatus) à la Martinique: Vers une régression du nombre de captures. Etudes 
Caribéennes, 1, 41-45.

[27] Dewynter, M. and Rufray, V. (2012) Le statut de conservation du Bothrops lanceolatus. Published Report for DEAL Martinique, Fort-de-France.

http://patrimoinemondial.airesprotegees.fr/files/2014/07/Biotope-2013-BD-Bothrop s-lanceolatus.pdf

[28] Lande, R. (1980) Genetic Variation and Phenotypic Evolution during Allopatric Speciation. American Zoologist, 116, 463-479. https://www.jstor.org/stable/pdf/2460440.pdf

[29] Caughley, G. (1994) Directions in Conservation Biology. Journal of Animal Ecology, 63, 215-244. http://www.jstor.org/stable/pdf/5542.pdf

[30] Daltry, J.C., Bloxam, Q., Cooper, G., Day, M.L., Hartley, J., Henry, M.R., Lindsay, K. and Smith, B.E. (2001) Five Years of Conserving the World's Rarest Snake: The Antiguan Racer Alsophis antiguae. Oryx, 35, 119-127.

https://www.researchgate.net/profile/Jennifer_Daltry/publication/227726363_Five_ years_of_conserving_the_\%27world\%27s_rarest_snake\%27_the_Antiguan_racer_A lso-

phis_antiguae/links/004635333585859638000000/Five-years-of-conserving-the-worl ds-rarest-snake-the-Antiguan-racer-Alsophis-antiguae.pdf

[31] Roge, J.P. and Sauvanet, J. (1987) Les serpents. Editions Saga, Cayenne.

[32] Barbosa-Fohrmann, A.P. and Kiefer, S.F.W. (2016) Para além do antropocentrismo: Uma proposta de reflexão. [Article title in English.] Revista Brasileira de Direito Animal, 11, 15-49. https://portalseer.ufba.br/index.php/RBDA/article/view/17661

[33] Descola, P. (2005) Par-delà nature et culture. Editions Gallimard, Paris.

[34] Bourgeron, P., Humphrie, H. and Riboli-Sasco, L. (2009) Regional Analysis of Social-Ecological Systems. Natures sciences sociétés, 17, 185-193. https://www.cairn.info/revue-natures-sciences-societes-2009-2-page-185.htm

[35] Moran-Ordonez, A., Bugter, R., Suarez-Seoane, S., de Luis, E. and Calvo, L. (2013) Temporal Changes in Socio-Ecological Systems and Their Impact on Ecosystem Services at Different Governance Scales: A Case Study of Heathlands. Ecosystems, 16, 765-782. https://doi.org/10.1007/s10021-013-9649-0

[36] Berkes, F., Colding, J. and Folke, C. (2003) Navigating Social-Ecological Systems: Building Resilience for Complexity and Change. Cambridge University Press, Cambridge.

[37] Lagadeuc, Y. and Chenorkian, R. (2009) Les systèmes socio-écologiques: Vers une approche spatiale et temporelle. Natures, sciences, sociétés, 17, 194-196. http://www.cairn.info/revue-natures-sciences-societes-2009-2-page-194.html

[38] Jassen, M.A. (2011) Resilience and Adaptation in the Governance of Social Ecological Systems. International Journal of the Commons, 5, 340-345.

https://doi.org/10.18352/ijc.320 